\title{
Eurostudia
}

\section{Learning to Master the Rules of the Game: A Study of Austrian Diplomats' Adaptation to the EU}

\section{Kathleen Angers}

Volume 12, numéro 1, 2017

L’Union européenne et le sentiment d'appartenance

The European Union and the Sense of Belonging

Die Europäische Union und das Zugehörigkeitsgefühl

URI : https://id.erudit.org/iderudit/1039780ar

DOI : https://doi.org/10.7202/1039780ar

Aller au sommaire du numéro

Éditeur(s)

Le Centre canadien d'études allemandes et européennes

ISSN

1718-8946 (numérique)

Découvrir la revue

Citer cet article

Angers, K. (2017). Learning to Master the Rules of the Game: A Study of Austrian Diplomats’ Adaptation to the EU. Eurostudia, 12(1), 46-69. https://doi.org/10.7202/1039780ar
Résumé de l'article

This article analyzes the impact of European Union membership on the practice of diplomacy among new member states. What does it mean, for a diplomat, to move from embodying the nation state to representing a member state? To generate a fine-grained account of the experience of adapting to the EU, I conduct an interview-based study of Austrian diplomats' adaptation to the EU following their country's accession in 1995. Borrowing from the sociology of Pierre Bourdieu, the interpretation of the data shows the cardinal importance for diplomats of learning to master the rules that have become taken-for-granted in the EU diplomatic field. Learning to deploy effective strategies in a new EU context, I argue, matters significantly more to the successful adaptation of diplomats than being socialized into a new identity does. This empirical finding suggests that the socialization literature in EU studies has not paid enough attention to social practices.
Tous droits réservés ( Le Centre canadien d'études allemandes et européennes, 2017
Ce document est protégé par la loi sur le droit d'auteur. L'utilisation des services d’Érudit (y compris la reproduction) est assujettie à sa politique d'utilisation que vous pouvez consulter en ligne.

https://apropos.erudit.org/fr/usagers/politique-dutilisation/ 


\title{
Kathleen Angers
}

Université de Montréal

\begin{abstract}
This article analyzes the impact of European Union membership on the practice of diplomacy among new member states. What does it mean, for a diplomat, to move from embodying the nation state to representing a member state? To generate a fine-grained account of the experience of adapting to the EU, I conduct an interview-based study of Austrian diplomats' adaptation to the EU following their country's accession in 1995. Borrowing from the sociology of Pierre Bourdieu, the interpretation of the data shows the cardinal importance for diplomats of learning to master the rules that have become takenfor-granted in the EU diplomatic field. Learning to deploy effective strategies in a new EU context, I argue, matters significantly more to the successful adaptation of diplomats than being socialized into a new identity does. This empirical finding suggests that the socialization literature in EU studies has not paid enough attention to social practices.
\end{abstract}

\section{Introduction}

The Europeanization and socialization of individual policy-makers and officials have been key themes in European Union (EU) scholarship of the last 15 years. Revisiting a neofunctionalist line of thought, a number of scholars inquired into the attitudes and behaviour of national officials involved in EU policy-making venues, examining whether social interactions at the European level may lead them to internalize supranational orientations or Brussels-based norms and rules (Egeberg 1999; Trondal 2001; Beyers and Trondal 2004; Beyers 2005; Lewis 2005; Checkel 2005; Quaglia et al. 2008; Howorth 2010). Elite socialization has also been identified, in several studies, as a key mechanism through which national policies, processes and institutions can be Europeanized (Börzel and Risse 2003; Bulmer and Radaelli 2004; Smith 2000; Wong 2005; Moumoutzis 2011; Alecu de Flers and Müller 2012). 
While pursuing the study of national policy actors' Europeanization, this article aims to go beyond a common problem in the aforementioned literature, namely the tendency to portray national actors as rule- or norm-followers. Indeed, the fact that member states' agents incorporate Brussels-based rules and norms is commonly interpreted, along the lines of March and Olsen's seminal distinction, as a "shift from a logic of consequences toward a logic of appropriateness" (Checkel 2005: 810). According to the former, human actors strategically "choose among alternatives by evaluating their likely consequences for personal or collective objectives,' while according to the latter they "follow rules that associate particular identities to particular situations" (March and Olsen 1998: 949-951). Hence, strategic action is presented as an alternative model to one in which actors are socialized by their environment. While some scholars have highlighted the coexistence of strategic and social logics of action in Council venues (Clark and Jones 2011; Juncos and Pomorska 2006), they have not provided an integrated theoretical understanding of how actors' behaviour is at once strategic and socially shaped.

In this article, I build on Pierre Bourdieu's sociology to investigate the impact of EU membership on the practices of new member states' diplomats. Increasingly mobilized in International Relations and EU studies (e.g. Pouliot 2008; Adler-Nissen 2008, 2013), Bourdieu's conceptual apparatus makes it possible to consider in an integrated manner the strategic dimension of national officials' EU practices and their embeddedness in a sphere of social relations at the European level. Accordingly, I argue that the Europeanization of national diplomats involves, first and foremost, developing a practical mastery of the taken-for-granted rules in the "EU diplomatic field." The latter refers to the social configuration wherein diplomats from the 28 member states interact and vie for influence over EU policies. Mastering the "rules of the game" in the EU diplomatic field allows one to deploy effective strategies in this struggle to influence EU policy-making. In sum, this argument underlies a conceptualization of agents as "rule-understanding" and strategic instead of rule-following (Mérand and Forget 2013).

The argument is demonstrated through a case study of Austrian diplomats' adaptation to the EU following the conclusion of Austria's accession negotiations 
in June 1994. The fact that Austria joined the EU relatively late in the history of the organization, but not as recently as the Eastern European members (2004 and 2007 enlargements), provides a suitable case to examine the long-term implications of EU membership for national officials. It allows for an investigation of what it means for officials to integrate a social environment that is already substantially institutionalized, and yet it offers the benefit of hindsight on the part of diplomats who have been involved in the EU for more than 15 years. Building on two dozen interviews with current and retired diplomats from the Austrian Ministry for Foreign Affairs, the article shows that Austrian diplomats went through a long-term and gradual process of learning to be more skilful actors in the EU diplomatic field. That process involved, among other things, learning to master EU temporality, including how to play strategically with time, and learning how to position their government advantageously in EU negotiations through practices of networking and displays of goodwill.

The first section of the article presents the Bourdieusian theoretical apparatus used for the empirical analysis and explains how I apply that framework to the specific context of diplomacy within the EU. Against this background, I analyse Austrian diplomats' experience of adaptation to the EU, after a brief presentation of the methodology.

\section{Bourdieu and the EU Diplomatic Field}

In Bourdieu's sociology, agents' practices result from the interplay between their habitus and the social field they encounter (Bourdieu and Wacquant 1992: 12021). Habitus is a set semi-conscious dispositions that agents acquire through social conditionings (i.e. through their trajectory in specific social fields) and which incline them to act, perceive and think in certain ways (Bourdieu 1990a: 5256). By virtue of its dispositional nature, habitus does not determine practices; instead, it is akin to a "grammar that provides a basis for the generation of practices" (Pouliot 2008: 274) and it can therefore trigger different practices depending on the social context or field that the agent encounters. The field is a social configuration in which individual or collective actors with knowledge of one another interact and struggle around a specific set of issues in accordance with taken-for-granted rules (Bourdieu 1993: 72-77). The latter, also called doxa, comprise all the ideas, norms and other forms of knowledge that are accepted as 
obvious in the field. Further, agents occupy unequal positions of power in the field, their position being determined by the capital they can draw upon. Capital refers to any type of resources, be it economic, social or cultural for instance, which for historical reasons specific to the field are valued in it and provide power.

Unlike the so-called logic of appropriateness, in a Bourdieusian perspective, agents are not rule-following, but rather "rule-understanding" (Mérand and Forget 2013: 98). A useful way to grasp this distinction is through Bourdieu's analogy between the dynamics of fields and that of a game; while rules are essential to the very existence of a game, the outcome of the latter and the players' moves are not mechanically determined by those rules (Bourdieu 1990b: 64). What matters for the players' success is what Bourdieu calls "practical sense" or the "feel for the game:"

The game is the locus of an immanent necessity, which is at the same time an immanent logic. In the game you cannot just do anything and get away with it. And the feel for the game, which contributes to this necessity and this logic, is a way of knowing this necessity and this logic. Whoever wants to win this game... must have a feel for the game, that is, a feel for the necessity and the logic of the game. (Bourdieu 1990b: 64)

Practical sense implies a situation of fit between an agent's embodied dispositions (habitus) and the structure of the field in which this agent is involved. Being endowed with practical sense in a given social situation is a source of success because it provides a practical mastery of the rules of the game and an ability to deploy effective strategies in that context. But practical sense is not a skill that all agents in the field are equally endowed with. While agents with an acute sense of the game can strategically manipulate the rules to their advantage, others may be playing the game with less ease and naturalness. Newcomers to a field are particularly likely to lack a sense of the game since they may not have inherited from their past experiences the specific dispositions (habitus) constituting practical sense in this field (Bourdieu 1990a: 52-64). If they want to stay in the game and have some success in it, these new agents must learn to master the rules of the game, that is to say, they must develop dispositions more in line with the field's practices so as to become more 
competent players. This process of alignment with the field is far from an automatic one however, habitus being path dependent and adaptation being constrained by the agent's capital.

As this conceptual presentation suggests, actors' behavior is strategic from a Bourdieusian point of view; in fact, strategies are inherent to the dynamics of fields. But, in contrast with a rationalist understanding of the concept, actors' strategies are socially shaped, both by their social trajectory (habitus) and by their current position in a field upholding a logic of practice of its own. Further, strategies are generated by agents' more or less conscious attempt at protecting and accumulating the capital that is valued in the field (Mérand and Forget 2013).

\section{The EU Diplomatic Field}

As suggested by Kauppi (2011: 154), the EU can be conceived as a "'superfield' that is composed of a variety of smaller-scale, relatively autonomous fields of action." The focus of this article is on one of these subfields, which I call the EU diplomatic field (see Adler-Nissen 2008 for a similar conceptualization). The latter is a structured space of social relations among the hundreds of diplomats and officials from the $28 \mathrm{EU}$ member states. In addition to the formal meetings within the various Council forums (committees, working groups, etc.), these actors interact regularly in various other venues (e.g. member states' capitals, third country capitals, etc.) as well as through emails and phone calls (Spence 2005; Batora and Hocking 2009). Through these interactions, member states' representatives struggle to influence EU decision-making to their government's advantage. To do so, they deploy strategies that, ideally, should build on a practical mastery of the formal and informal rules of the EU diplomatic field and on a sense of their position within the field's hierarchy of actors.

The EU diplomatic field is structured by a number of taken-for-granted rules. One of these tacit understandings relates to the temporality of the field's practices. As Ekengren (2002) showed, a fundamental implication of European governance is that it integrates national policy-makers into a common temporal logic, that is, a common set of time horizons, deadlines and rhythms. Indeed, taking part in the EU game is to work according to its specific temporality, with its schedule of weekly, monthly and yearly Council meetings, its Council 
presidency agenda, etc. Conversely, "ignoring the game's rhythm, tempo and directionality is to stand out of the game," as Bourdieu writes (1990a: 81-82). Adler-Nissen (2011: 1099) highlights another undisputed premise of the EU diplomatic field, namely the idea that the EU "must continue to move forward," which is "a shared assumption - or doxa - that is very rarely questioned by any national or EU official during negotiations." While in some policy fields this doxa is enacted through supranational law, in others, such as the CFSP area, it is enacted through intergovernmental practices of information sharing, consultation and coordination (Smith 2000; Keukeleire and MacNaughtan 2008).

In line with the premise that the EU must keep moving forward, the work of the Council depends, as Hayes-Renshaw and Wallace (2006: 17) write, on a "crucial assumption that there is give and take between the positions of the member states and that, whatever the starting positions of the member states, there is both scope for those positions to evolve and a predisposition to find agreement." Thus, the work of the Council relies on a culture of compromises and consensus, and on a predisposition "to make things work" (Lewis 2005; Haroche 2009; Howorth 2010). The consensus-seeking "assumption" in the Council implies that, regardless of the voting rule, negotiators tend to continue discussions until everyone is "on board" (Lewis 2005; Hayes-Renshaw and Wallace 2006). In sum, understanding and mastering all these taken-for-granted rules and norms of the EU diplomatic field allows one to accumulate capital in the form of credit from the other participants, which is a highly valuable resource in the field.

Another valuable resource in the field, which clearly impacts on the position of power of each member state and their representatives, is organizational capital. The French and the British, in particular, can count on much more important organizational resources (staff, financial means and centralization) than many small or medium-size member states that have smaller and less centralized administrations (Hayes-R. et Wallace 2006; Haroche 2009: 67). These resources enable them to develop more expertise on more issues, take position on all the important questions, and potentially increase the speed and

\footnotetext{
${ }^{1}$ Similarly, Lewis $(2005,939)$ notes that the "standards of appropriateness found in Coreper include... a duty to 'find solutions' and keep the legislative agenda of the Council moving forward."
} 
efficiency with which they operate in the whole negotiation process. Other sources of inequality include the fact that member states have different voting power in the Council (except in the CFSP area) and the tendency for the larger member states - France, Germany and the UK - to set the agenda in the CFSP domain, given their greater capital (material resources and credit from the other actors) in matters of foreign and security policy (Keukeleire and Macnaughtan 2008).

Furthermore, inequalities within the EU diplomatic field are generated by the fact that some member states have joined the organization much later than others. As pointed out by Hayes-Renshaw and Wallace (2006: 248-49), "newcomers tend to be disadvantaged players of the game at first," since they have to learn the Council's complex procedures, its formal and informal rules, "what lines of argument in defence of a national position will be likely to attract support from other European-level actors and where possible alliances can be forged." In order to achieve their mandate as national representatives and policymakers, diplomats from the new member states must not only learn what the rules are, but learn how to play strategically with them, that is, learn how to use them in a way that will generate capital and position their government advantageously towards the other member states.

In sum, the Bourdieusian framework used in this study suggests a shift in the usual understanding of state actors' socialization in the EU. State agents do not simply conform themselves to the rules and norms structuring interaction at the EU-level, thereby evolving away from strategic action and internalizing new subjective commitments. Instead, actors' socialization ${ }^{2}$ is driven by a ruleunderstanding logic whereby they gradually develop more practical sense, which enables them to better master the rules of the game and therefore be more competent strategic actors. This Bourdieusian framework makes it possible, therefore, to overcome the dichotomized view of culture and strategy which is so common in the Europeanization literature (see Williams 2007 for a similar

\footnotetext{
${ }^{2}$ It should be noted that socialization taking place in the context of EU work is most likely a very secondary type of socialization. Primary socialization, which takes place during childhood, schooling and within a first career environment is much more formative of an individual's dispositions (Swartz 1997).
} 
argument regarding the constructivist literature in security studies). In turn, this should allow for a better understanding of officials' lived experience of the EU.

\section{Methodology}

Building on the approach laid out in the previous section, I study Austrian diplomats' experience of adaptation to the EU following the conclusion of Austria's membership negotiations in June $1994 .^{3}$ The selection of this case is premised on the idea that, Austria's integration in the EU being not as recent as the last rounds of enlargement (2004, 2007 and 2013), it should allow for a more long-term perspective on the implications of EU membership for the practices of national officials. Such a long-term perspective is especially relevant considering the theoretical framework adopted here, according to which "adapting" to a new social field is a process evolving over a long period of time. Yet, the integration of Austria in the EU was not too old at the time of data-collection as to make it impossible to find interviewees who had not known, as diplomats, the period before their country joined the EU.

I conducted 24 interviews with current and retired (8 of them) career diplomats from the Austrian Ministry for Foreign Affairs (MFA). ${ }^{4}$ The interviewees were mostly middle- or high-ranking officials holding or having held in the past a position either as national representative in one of the preparatory bodies of the EU Council or as official in the Political or Economic Affairs' sections of the MFA in Vienna. The interviews lasted 60 minutes on average and were based on a semi-structured interview guide tailored to the professional trajectory of the interviewee. Through these interviews, I sought to obtain the participants' recollection of what their integration in the EU had meant for their working practices in the first years of their membership and up to these days, that is, what kind of adaptation, if any, it has involved in their practices to become involved in the whole EU "machinery." Beyond questions raising explicitly the issue of adaptation, I also sought to obtain descriptions from the interviewees about how they (either themselves personally or the Austrian MFA

\footnotetext{
${ }^{3}$ The empirical research conducted for this article was part of a larger project on the implications of European integration for the Austrian diplomacy.

${ }^{4}$ The interviews were conducted anonymously.
} 
54 The European Union and the Sense of Belonging

in general) currently (i.e. at the time of the interviews) handle their EU membership in terms of negotiation practices.

\section{Austrian diplomats in the EU diplomatic field}

This section shows that following their integration in the EU diplomatic field, Austrian diplomats went through a process of learning to become more competent players and, accordingly, developed strategies in line with the takenfor-granted rules in the field. Three dimensions of that process of adaptation are examined:

1) developing a mastery of EU temporality; 2) accumulating social capital through networking; 3) accumulating capital through constructive behaviour. Before turning to the first of these three dimensions, it is worth quoting two interviewees whose comments suggest that Austrian diplomats lacked practical sense at the beginning of their EU membership and needed time to become more "masters at the game," that is, more skilful at promoting Austrians' interests in the EU:

You are not necessarily very skilful on day one. ... I must say that, from June on [1994], our people were allowed to sit as observers in various EU forums, including the Council.... And that I think was a very good learning process. Because [we] had the opportunity to get to know the procedures, get to know the people, get to know the way of operating. ... But between knowing what the rules are and how the game is being played, and actually using all these procedures in a skilful way, that is a long way, that takes years to actually know how to use different tricks, play tricks on the rules of procedures and so on, that takes more time. So it was a very gradual process. (Interview 15, July 2009)

You could see that we had advanced significantly by the time of the second [Austrian] presidency; when 2006 came around we were much more, you know, into the game than we were in 1996 when we prepared for 1998. 1998 really was a presidency where we thought, we had to do it well but we won't, how should I say; no particular initiatives, there were very few sort of Austrian initiatives. In 2006 we were more proactive; we had the Balkans initiative... It showed we were more masters at the game than we had been 8 years earlier. It's a normal learning curve. (Interview 10, July 2009) 


\section{Mastering EU Temporality}

Several interviewees talked about temporal changes (the faster pace of work in particular) as the most, or one of the most, significant implications of joining the EU. Their comments suggest that they had to learn to master EU temporality by, first of all, speeding up their work rhythm simply to manage to meet EU deadlines and be able to follow minimally the flow of the game. For instance, in the first years of their EU membership, diplomats in the MFA's Political Affairs section had to develop an ability to process information more quickly in order to find their way through abundant CFSP-related communication flows among EU foreign ministries (Interviews 4, 10, 17). In this regard, a diplomat talked about her beginnings as European Correspondent ${ }^{5}$ at the end of the 1990s in these terms: "I think in the beginning what you have to learn is how to cope with that flow of information. Because: A) it speeds up the process enormously; and B) you have to somehow sort through it, sort out the important stuff and that again is a learning curve" (Interview 10, July 2009). Also in the context of CFSP, other interviewees highlighted the need, brought by their integration in the EU diplomatic field, to work faster so as to react in a timely manner to their colleagues' exchanges of information or demands for positioning:

Everything is going much faster, because you have to react much faster, there is no time for reflection. I mean it goes back and forth; it's a constant stream of emails and information going back and forth, so the speed is much higher. (Interview 23, July 2009)

...the work rhythm is much different. We were used to - okay, the mission at the UN asking for instructions... unless they said it's in two hours, you usually had the time to think... With the COREU, ${ }^{6}$ when the presidency sends out a COREU and says... tomorrow $2 \mathrm{o}^{\prime}$ clock, if you don't answer by then, you are supposed to have agreed. And this happens, I don't know, 20 times a day. So the whole work rhythm is very different than what we were used to before. (Interview 17, July 2009)

\footnotetext{
${ }^{5}$ European Correspondents are responsible, in each member state and the Commission, for the routine aspects of CFSP, including the preparation of instructions for the meetings of the Political and Security Committee in Brussels.

${ }^{6}$ The COREU is a communication network between the foreign ministries of the EU member states, the Commission and the Council secretariat (Spence 2005).
} 
Beyond the need to speed up their working practices so as to react on time, interviewees suggested that mastering the EU temporality also involved a more proactive dimension, which consists mainly in a skill at anticipating the forthcoming. This skill at anticipation was apparently lacking within the MFA at the beginning of Austria's EU membership, as this quotation suggests:

In the very beginning, what the EU required for us, how should I say, as a neutral country between two blocs, you would normally, in the cold war, Austria [the MFA] would first have to wait what the two blocs would define as their position and then you would try to find the middle ground, ... a niche for yourself. So it was more a reactive position we were in. In the EU, you're then for the first time in a position where you have to define your interest very early on, very often before the Commission makes a proposal, so in that sense it pushed us into a more active role, and that took a few years, to put it bluntly. Because to change the whole way you operate: you know, reactive to pro-active, there's a change, so it took us quite a while to get used to that. And to some degree, it was even difficult to define our positions and our interests because we were not so used to doing that, you know, clearly sitting down and defining in the next year or so we will have this concern or this interest. But over the years, it just sort of happen; you adapt to that, you speed up your process... It's still something that's difficult because for small administrations like ours... it's more difficult to see where the Commission might come up with something problematic and you have to try to influence that very early on. (Interview 10)

Hence, according to this extract, Austrian diplomats (or part of them at least) learned through time to operate in a more proactive manner by anticipating their government's policy interests much more in advance than before. Such evolution, even if "still difficult" due to a lack of organizational capital, reflects a process of developing a greater sense of the game since actors who can anticipate their interests have of course more chance, thanks to a longer time horizon, to influence EU decision-making to their advantage. In fact, Ekengren (2002: 138) confirms this view when he remarks that "a mastery of the temporal dimension of European governance requires an ability to plan and foresee up-coming situations (agenda items, potential coalition partners, etc.) in the rhythm of 
meetings" and that such mastery is "regarded as high competence" among national officials within the EU.

While describing his practices upstream the Council negotiations, another diplomat who worked for the first time as Austrian negotiator in the Council at the end of the 1990s expressed the strategic value of anticipation combined with a sense of the urgency of the game:

Contacts with the Council Secretariat: it's so important because they organize all the work and if you know how the work is organized, you can guess what will be the situation in the following week or so, so you would have an understanding of what will be the near future, what are the next steps, what are the next initiatives in the corner. It's so important to know, never to be surprised by any move by somebody, to know as much as you can in advance. And then you have to have good contacts with experts of the Commission, because the Commission is where the initiatives come from, and where most of the papers come from. And if you have the chance to discuss things with an expert before experts draft the documents, it gives you an enormous advantage, because not only you can learn how a Commission expert is likely to draft in this or that matter a document and would not take into consideration other alternatives, but you can try to influence his way of thinking if you have a good argument on your side. (Interview 1)

The practices just described, aimed as they are at gaining an advantage in the game, are strategic moves that are arguably derived from an embodied practical sense. "Urgency," Bourdieu writes (1990a: 82), "is the product of playing in the game and the presence in the future that it implies... the feel for the game is the sense of the imminent future of the game." And with a sense of urgency comes awareness of the importance of quick work and a sense of timing, as suggested by these comments from two diplomats posted in Brussels in former years:

You have to be fast, really. Because in the EU, it's not the big ones who eat the small ones, it's the fast ones who eat the slow ones. So if you are a small country, like Austria, you can be as good as big ones if you are fast, have good ideas, if you contribute something. (Interview 20) 
Time and quick work is so important. When I was the representative for the enlargement working group, I would write the report the same day; we would finish the meeting at $6 \mathrm{pm}$ and then I would work until 2am to have the report ready and send it in the middle of the night, to make sure that when the colleagues start to work in the morning, they have the full report of the meeting. ... In bilateral [postings], it doesn't matter if you take 2 or 3 days to send a report. (Interview 1)

\section{Accumulating Social Capital through Networking}

Interviewees frequently portrayed networking, whether explicitly or not, as a practice that themselves and their Austrian colleagues had to develop further once they joined the EU. When asked to assess Austria's overall performance in terms of influence in Brussels, one of the MFA's former EU permanent representative states, "At the beginning [of Austria's EU membership], no [we did not do very well], we didn't know the networking and everything, but we learned a lot" (Interview 20). Another retired diplomat highlights the novelty for Austrian officials of networking requirements in the EU: "if you have something special you want the Union to do for us, you have to build networks, coalitions and things like that, so it's a completely different life-style" (Interview 26). Going along with this remark, one of the MFA's current diplomat notes that conducting foreign policy as an EU member has required "a new form of networking experience if you want to realize your interests, finding partners among the member countries of the EU, creating a network of friends and trust and common interests" (Interview 24).

In a Bourdieusian perspective, networking is about accumulating social capital, which refers to "the set of resources linked to possession of a durable network of more or less institutionalized relationships of mutual acquaintance and recognition" (Bourdieu 1980: 2). It is "the product of social investment strategies consciously or unconsciously oriented towards the institution (or reproduction) of social relations directly usable, in the short- or long-term" (Bourdieu 1980: 2). Of course, in a multilateral decision-making forum like the EU Council, national representatives in Brussels have no choice, unless they decide to step out of the game, but to constantly engage in informal talks upstream of the formal meetings in order to find out about each government's position on 
ongoing negotiations, forge compromises, mobilize support and build coalitions (Haroche 2009; Hayes-Renshaw and Wallace 2006). Austrian diplomats have therefore got involved in that process of constant networking, not only in Brussels but also in other capitals of the EU member states (Interviews 4, 5, 10, 19, 23). Austria's bilateral embassies in the EU have seen their functions largely redirected on EU issues (Neuhold 2005), as a diplomat formerly posted in Malta explains:

When you're ambassador in an EU country like I was in Malta, nearly everything you do is EU-related. ...We opened our embassy in Malta after they joined the EU specifically with the interest of finding as many... common grounds, trying to figure out how the Maltese would act or both or, you know, give the background to their positions and at the same time lobby for Austria's interests and get Maltese' support where we could. (Interview 10)

Naturally, informal networking is all the more crucial when one wishes to push an initiative in the EU. In such cases, all levels and occasions of contacts between Austrian officials and their EU partners need to be used to mobilize support (Interviews 10, 23).

In the context of CFSP, most Austrian diplomats posted to third countries and international organizations have also become engaged in cultivating close ties with their EU counterparts, in part through the regular EU ambassadors' group meetings but also through more informal contacts (Interviews 4, 5, 8). Doing so has allowed them to accumulate capital not only by enacting the EU norm of member states' consultation abroad, but also by increasing their level of information, as one diplomat observes:

I had the feeling that, particularly as a small country, you get much more information if you can join the ambassadors' meetings or the deputy ambassadors' meetings. Like in Tunis, we had it once a month amongst the deputy ambassadors... and certainly you get much more information because you know people talk about what they think, what they have heard... (Interview 8). 
A senior diplomat in charge of legal and consular affairs in the MFA illustrates another strategy to accumulate social capital:

I make a point of always going to the country [that] will have the presidency the next half year... to sort of get to know the presidency, find out about their projects, tell them about what's important to us, so they know what to expect from us, things like that. ... It's important to explain what our position is and to find out what their projects are, simply because sometimes there's a lack of knowledge about the conditions in a particular country and as long as you didn't find out about these backgrounds, it's very hard to find compromises at the European level. (Interview 15).

Through such bilateral visits, based on transparency, responsiveness and sociability with EU partners (which are valued practices in the EU diplomatic field, see e.g. Haroche 2009), this diplomat is likely to accumulate a capital of confidence that will be profitable for Austrian interests during the course of negotiations in Brussels.

While most of the networking practices talked about so far "depend on what is at issue" on the EU agenda (Interview 15), the Austrian MFA has been engaged since 2000 in a long-term strategy which consists in acquiring more permanent allies among the EU member states, on the model of such informal "friendship groups" as the Benelux states (Belgium, Netherlands, Luxembourg). In August 2000, shortly before the lifting of the so-called "sanctions"7 of the EU14 against Austria, Benita Ferrero-Waldner, the Austrian foreign minister, advocated the deepening of cooperation with the neighboring Central and Eastern European countries that were candidates to EU accession (Luif 2012). For some, the sanctions' episode was highlighting the fact that, as an Austrian diplomat put it, "Austria lacks natural partners in Europe to secure its interests" (Prosl 2000, in Luif 2012). In 2001, the foreign ministers of Austria, the Czech Republic, Hungary, Slovakia, Slovenia and Poland officialized the creation of a "Regional Partnership" whose goals were to facilitate the European integration of Austria's five partners, intensify cross-border cooperation in various areas and,

\footnotetext{
7 These punitive measures, which lasted from February to September 2000, were aimed at protesting against the inclusion of the right-wing populist Freedom Party (FPÖ) in the federal governmental coalition.
} 
following their EU accession, to support one another in coordinating positions in EU negotiations and doing joint intra-EU lobbying (Ehrlich 2002). Despite the decreasing role of this partnership over the years and the difficulties encountered by Austrian officials in trying to deepen their country's relationships with the Central and Eastern European member states (Luif 2012; Gehler and Bischoff 2006), the idea of strategic solidarity with these countries was still alive in at the time of my interviews:

We try to have a very close relationship with our Eastern neighbors, including countries like Poland or Croatia... So that is an issue of maintaining good neighborly context, but also an issue of getting together a group which can act together in the bigger EU framework. Because... [with] our Eastern and South-Eastern neighbors... we have so much in common that we can, you know, in many very cases form useful ad hoc alliances. (Interview 7)

\section{Accumulating Capital through Constructive Behavior}

The third set of adaptive strategies that was discernible in my interviews relates to the assumptions of compromises and consensus in the EU diplomatic field. Several interviewees suggested that the Austrian MFA has developed the overall strategy, in EU negotiations, of limiting uncompromising stances to very few issues - which are of a particular concern for Austria because of geography for instance or special sensitivities among the Austrian public (e.g. nuclear power) while being cooperative and supporting the mainstream EU position on most subjects (Interviews 1, 7, 10, 14, 15):

We choose our issues I would say. What you can do in the EU is you can be destructive very easily; you can just say no to certain things... However you don't do that very often as a smaller country; again you sort of choose where you say this is my bottom line and I can't go beyond that. On nuclear issues for example, where we have a very strong, very outspoken position against nuclear power, they know that they can't go in a certain direction in consensus language... because at least one member, Austria, will never agree to that. ... [But] in general Austria tries to remain in the mainstream. ... There are other countries that take more extreme stances. We very rarely do, simply because it's not in our national interest. (Interview 10) 
Arguably, the logic underlying the judgement that frequently dissenting from the mainstream position is not in Austria's "national interest" lies in the understanding that such behaviour is detrimental to Austrians' capital in the EU diplomatic field. As already argued by others (especially Adler-Nissen 2008), behaving in a constructive way, displaying goodwill and being helpful to others during negotiations are ways to accumulate capital in the Council system. Interviewees suggested that accumulating such "goodwill capital" is crucial to their ability to obtain EU colleagues' support and conciliatory attitude in those few occasions when their government really cannot join the mainstream or when it want to put forward a particular EU initiative (Interviews 1, 7, 15, 20). Two diplomats explicitly highlighted this logic of reciprocity with respect to the CFSP area:

[In the CFSP area], that was quite a challenge to... find one's way to put focus on certain things, find out how, in the regions where you have very particular interests, you can make yourself heard among 14 more member states - which may have rather different interests - in particular if you are small. So this is an art of networking. And also, I think for a small country to make it clear, we are there, we work with you on all the different subjects, we are not going to interfere with many of them, but once we say this is very important for us, then please you have to take account of that. And that's the kind of position you have to carve for yourself. (Interview 15)

Theoretically, you have the possibility to say no, I don't want this... but I think you must be very, how should I say, you must be very choosy about where to make such a stand if it's necessary at all. I mean, the patience of partners is limited, so... having a reputation of blocking the process for relatively unimportant things is probably not good for you if you want to, you know, push something... (Interview 7)

One interviewee suggested that accumulating capital through constructive behavior can (and should) also be done in a more proactive manner. After having developed his point that "smaller countries have to select which are the areas 
where they have a particular word or point of view to bring to the discussion," 8 he makes the following comment:

The danger is that you say something only when you have to defend your position. And this you have to avoid. You have also to come in with helpful positions, compromises even if it doesn't concern your own country... it is seen as positive... the Irish, the Dutch and the Luxembourgers are good at it. They keep an active role - especially Luxembourg. There are so many things and political fields of activity where Luxembourg is not important, but nevertheless they try to understand others' problems and come with suggestions and ideas and this makes them be seen as a very active and positive factor in the negotiations. And if they want something for themselves, it's much easier to get it. (Interview 1)

When asked how Austrian officials fare regarding such proactive attitude, the interviewee replies: "We try to learn from countries like the Dutch and the Irish" (Interview 1).

\section{Conclusion}

Drawing on Pierre Bourdieu's theory of practice, this article has highlighted the central importance, with respect to national actors' Europeanization, of competence and know-how in tune with the social structure of the EU diplomatic field. Understanding what is possible, feasible and acceptable in the latter, given the configuration of formal and informal rules and the distribution of resources, and acting out that understanding through skilful strategies are essential to achieving national objectives. Hence, I have argued that the Europeanization of new member states' agents (who are particularly likely to lack practical sense in accord with the EU game) crucially involves developing their practical mastery of the rules of the game in order to play their role as national policy-makers and representatives. In the case of Austrian diplomats, this has meant, notably, learning to master the EU temporality, learning to master practices such as networking so as to accumulate social capital, and adopting practices of

\footnotetext{
${ }^{8}$ For example:

...when it comes to road traffic, on that subject... the point of view of Austria is of special importance and will receive, when Austrians say something, special attention. On the other hand, about maritime safety for example; Austria doesn't have ships, so it's not nice from the Austrian representative to have a very particular point of view (Interview 1, June 2009).
} 
negotiation in tune with the expectation of constructive behaviour in the EU diplomatic field.

The literature has often hypothesized, on the basis of sociological institutionalist or constructivist insights, that involvement in EU policy-making could have transformative effects (thanks to socialization processes) on national actors' identity or self-understandings, on their beliefs, values or interests (e.g. Checkel 2005). Then some scholars have shown that this was not supported, or weakly supported, by the empirical evidence (see Zürn and Checkel 2005; Hooghe 2005; Beyers 2010; Clark and Jones 2011), which led some of them to conclude that "Europeanization is not transformative" for individual state agents (Clark and Jones 2011: 362). In this article, I have shown that getting involved in the EU social environment has been transformative for Austrian diplomats, but not in the way much of the literature has usually portrayed the effects of this social setting; Austrian diplomats went through a process of developing new practical logics, dispositions and skills in line with the social structure of the EU diplomatic field, but this process has not required changes in their identity, beliefs or values, however.

In sum, this article has suggested a shift in the usual understanding of state actors' socialization in the EU. Europeanists have largely interpreted socialization as a process whereby individual actors evolve away from strategic action by internalizing group rules and norms, and in doing so develop new selfunderstandings (e.g. Beyers 2010; Checkel 2005). By contrast, I have put forward, based on Bourdieu's sociology, a view of socialization as a process implying the acquisition of practical sense. Acquiring practical sense means acquiring dispositions (ways of acting, of thinking and being) that are valued in a given social field, which does not imply an evolution away from strategic action, nor a change in one's sense of identity. In brief, such an understanding of socialization shifts attention away from the internalization of ideas and identities by individual actors to focus instead on their practices, skills and strategies in a given social context. Considering that the internalization of new subjective commitments (ideas, values, identity) by national officials involved in the EU is very limited according to empirical research (Zürn and Checkel 2005; Beyers 2010; Hooghe 2005; Egeberg 1999), such a shift appears particularly warranted. 


\section{References}

Adler-Nissen, R. (2008). "The Diplomacy of Opting Out: A Bourdieudian Approach to National Integration Strategies," Journal of Common Market Studies 46(3): 663-84.

- (2011). "Opting Out of an Ever Closer Union: The Integration Doxa and the Management of Sovereignty," West European Politics 34(5): 1092-1113.

—. (ed.) (2013). Bourdieu in International Relations: Rethinking Key Concepts in IR. London, Routledge.

Bátora, J. and B. Hocking (2009). "EU-Oriented Bilateralism: Evaluating the Role of Member State Embassies in the European Union," Cambridge Review of International Affairs 22(1): 163-82.

Beyers, J. (2005). "Multiple Embeddedness and Socialization in Europe: The Case of Council Officials," International Organization 59: 899-936.

Beyers, J. and J. Trondal (2004). “How Nation States 'Hit' Europe: Ambiguity and Representation in the European Union," West European Politics 27(5): 919-42.

Beyers, J. (2010). "Conceptual and Methodological Challenges in the Study of European Socialization," Journal of European Public Policy 17(6): 909-20.

Börzel, T. and T. Risse (2003). "Conceptualizing the Domestic Impact of Europe." In Featherstone, K. and C. Radaelli (eds.) The Politics of Europeanization. Oxford, Oxford University Press.

Bourdieu, P. (1980). "Le capital social," Actes de la recherche en sciences sociales 31: 2-3.

—. (1990a). The Logic of Practice. Cambridge, Polity Press.

—. (1990b). In Other Words: Essays towards a Reflexive Sociology. Stanford, Stanford University Press.

—. (1993). Sociology in Question. London, Thousand Oaks: Sage.

Bourdieu, P. and L. Wacquant, L. (1992). “The Purpose of Reflexive Sociology.” In P. Bourdieu and L. Wacquant (eds.) An Invitation to Reflexive Sociology. 
Chicago, University of Chicago Press, p. 60-215.

Bulmer, S.J. and C.M. Radaelli (2004). "The Europeanisation of National Policy?" Queen's Papers on Europeanization, $\mathrm{n}^{\circ} 1$.

Checkel, J. (2005). "International Institutions and Socialization in Europe: Introduction and Framework," International Organization 59(4): 801-26.

Clark, J. and A. Jones (2011). “'Telling Stories about Politics': Europeanization and the EU's Council Working Groups," Journal of Common Market Studies 49(2): 341-366.

Egeberg, M. (1999). “Transcending Intergovernmentalism? Identity and Role Perceptions of National Officials in EU Decision-making," Journal of European Public Policy 6(3): 456-74.

Ehrlich, W. (2002). "Regional Partnership: An Austrian Initiative." In Luif, P. (ed.) Regional Partnership and the Future of the European Union, Working paper 41, Austrian Institute for International Affairs, Vienna, p. 35-40.

Ekengren, M. (2002). The Time of European Governance. Manchester, Manchester University Press.

Gehler, M. and G. Bischof (2006). "Austrian Foreign Policy after World War II." In Bischof, G., Pelinka, A. and M. Gehler (eds.), Austrian Foreign Policy in Historical Context. New Brunswick, N.J.: Transaction Publishers, p. 1-24.

Haroche, P. (2009). L'Union européenne au milieu du gué. Entre compromis internationaux et quête de démocratie. Paris, Economica.

Hayes-Renshaw, F. and H. Wallace (2006). The Council of Ministers. Houndmills; New York, Palgrave Macmillan.

Hooghe, L. (2005). "Several Roads Lead to International Norms, but few via International Socialization: A Case study of the European Commission," International Organization 59(4): 861-98.

Howorth, J. (2010). "The Political and Security Committee: A Case Study in 'Supranational Intergovernmentalism'," Les Cahiers européens de Sciences Po ${ }^{\circ}$ 1. 
Juncos, A. and K. Pomorska (2006). "Playing the Brussels Game: Strategic Socialisation in the CFSP Council Working Groups," European Integration online Papers 10.

Kauppi, N. (2011). "EU Politics.” In A. Favell and V. Guiraudon (eds.) Sociology of the European Union. Houndmills, Palgrave Macmillan.

Keukeleire, S. and j. MacNaughtan (2008). The Foreign Policy of the European Union. Basingstoke; New York, Palgrave Macmillan.

Lewis, J. (2005). “The Janus Face of Brussels: Socialization and Everyday Decision Making in the European Union," International Organization 59: 937-971.

Luif, P. (2012). "Austria and Central Europe." In Sabik, Z. and P. Drulak (eds.) Regional and International Relations of Central Europe. Houndmills, Palgrave Macmillan.

March, J. G. and J. P. Olsen (1998). "The Institutional Dynamics of International Political Orders," International Organization 2(4): 943-69.

Mérand, F. and A. Forget (2013). "Strategizing about Strategy." In R. AdlerNissen (ed.) Bourdieu in International Relations: Rethinking Key Concepts in IR. London, Routledge, p. 93-113.

Moumoutzis, K. (2011). “Still Fashionable Yet Useless? Addressing Problems with Research on the Europeanization of Foreign Policy, Journal of Common Market Studies, 49(3): 607-629.

Müller, P. and N. Alecu de Flers (2012). "Dimensions and Mechanisms of the Europeanization of Member State Foreign Policy," Journal of European Integration 34(1): 19-35.

Neuhold, H. (2005). “Austria.” In Hocking, B. and D. Spence, Foreign Ministries in the European Union. Integrating Diplomats. Houndmills, Palgrave-Macmillan, p.37-59.

Pouliot, V. (2008). “The Logic of Practicality: A Theory of Practice of Security Communities," International Organization 62(2): 257-88. 
Quaglia, L., De Francesco, F. and C. Radaelli (2008). “Committee Governance and Socialization in the European Union," Journal of European Public Policy 15(1): 155-166.

Smith, M. E. (2000). "Conforming to Europe: The Domestic Impact of EU Foreign Policy Co-operation," Journal of European Public Policy 7(4): 613-631.

Spence, D. (2005). "The Evolving Role of Foreign Ministries in the Conduct of European Union Affairs." In Hocking, B. and D. Spence (eds.) Foreign Ministries in the European Union. Integrating Diplomats. London, Palgrave Macmillan Press, p. 18-36.

Swartz, D. (1997). Culture and Power: The Sociology of Pierre Bourdieu. Chicago, The University of Chicago Press.

Trondal, J. (2001). "Is there any Social Constructivist-institutionalist Divide? Unpacking Social Mechanisms Affecting Representational Roles among EU Decision-makers," Journal of European Public Policy 8 (1): 1-23.

Williams, M. C. (2007). Culture and Security: Symbolic Power and the Politics of International Security. London. Routledge.

Wong, R. (2005). “The Europeanization of Foreign Policy." In Hill, C. and M. Smith (eds.) International Relations and the European Union. Oxford, Oxford University Press.

Zürn, M. and J. Checkel (2005). "Getting Socialized to Build Bridges: Constructivism and Rationalism, Europe and the Nation-state," International Organization 59(4): 1045-79.

\section{Interviews}

Interview 1, June 2009, Federal Ministry for European and International Affairs, Vienna.

Interview 4, June 2009, Federal Ministry for European and International Affairs, Vienna. 
Interview 5, June 2009, Federal Ministry for European and International Affairs, Vienna.

Interview 7, June 2009, Federal Ministry for European and International Affairs, Vienna.

Interview 8, July 2009, Federal Ministry for European and International Affairs, Vienna.

Interview 10, July 2009, Federal Ministry for European and International Affairs, Vienna.

Interview 14, July 2009, Federal Ministry for European and International Affairs, Vienna.

Interview 15, July 2009, Federal Ministry for European and International Affairs, Vienna.

Interview 17, July 2009, Vienna.

Interview 19, July 2009, Vienna.

Interview 20, July 2009, Vienna.

Interview 23, July 2009, Federal Ministry for European and International Affairs, Vienna.

Interview 24, July 2009, Federal Ministry for European and International Affairs, Vienna.

Interview 26, July 2009, Vienna. 